\author{
T. Muravska ${ }^{1}$, L.A. Medukhanova ${ }^{2}$ (D), A.Zh. Bekmurza² \\ ${ }^{1}$ Business Administration, Riga Stradiňš University, Latvia, Riga \\ ${ }^{2}$ Al-Farabi Kazakh National university, Kazakhstan, Almaty, \\ e-mail: medukhanova.1@gmail.com
}

\title{
PROBLEMS OF DEVELOPMENT AND EFFECTIVE USE OF HUMAN CAPITAL IN DEVELOPING COUNTRIES
}

\begin{abstract}
The article discusses main problems of development of human capital in developing countries. The main purpose of the article is to identify problems of effective use of human capital in developing countries. The relevance of the article is to justify the economic content of human capital, to analyze the basic indicators and indices of human capital development in developing countries in comparison with other countries of the world, to make a comparative analysis of the problems of effective use of human capital by countries, and the World Bank's role in the development of human capital. The article identifies problematic issues of projects for the development of human capital. The general methodological basis of the article is the general scientific methods of knowledge used for the theoretical analysis of economic phenomena. The results of the study confirm the need to make additions to human capital development programs and the need to create conditions and factors for its effective development in order to create an innovative economy of the future. The ways of improving human capital development programs are proposed.

Key words: human capital, developing countries, human capital index, efficient use of human capital, integrated
\end{abstract} assistance.

Introduction. The last two decades of management science have passed under two banners: "innovation" and "human resources". This time can be characterized by a complication of the external organizational environment, a sharp increase in the pace of its change and fiercer competition in world markets. All these phenomena required the search for hidden reserves and new ways to increase efficiency. Thus, the concept of human capital and its theory arose in the second half of the twentieth century, as a response of economic science to the challenges of the time, to the accelerated formation of an innovative economy, post-industrial and information societies. The role of specialists and workers of intellectual labor in the modern economy has grown tremendously. The role and share of unskilled labor, on the contrary, has decreased and continues to decline with the beginning of the formation of a knowledge economy. It is the "human resource" or "human potential" that has become the resource that hides the largest reserves for increasing the efficiency of the functioning of a modern organization. "Human capital" has come to be seen as a more important object of investment than factories, equipment, technologies, etc.

Besides, the development of a modern economy, increasing its competitiveness is impossible without the accumulation and development of human capital, since the foundation of the transformation of the economic system into an innovative economy is human capital. In this regard, the level of development and the efficient use of human capital is of paramount importance.

Literature Review. This research aims to identify the problems of effective use of human capital in developing countries in the framework of South Asian developing countries. The general methodological basis of the thesis is the general scientific methods of knowledge used for the theoretical analysis of economic phenomena. Economic and statistical research methods, comparison, dialectical methods of cognition of the phenomenon from general to particular are also used.

There is a large body of literature that has revealed that one of the most important factors of economic growth is human capi- 
tal (Pelinescu, 2015: 184-190). The economist Fisher bluntly stated that «wealth in the broadest sense includes people» (Fisher I, 1906: 168)

Caring for economic growth, governments prefer to invest in real capital - new roads, beautiful bridges, shining airports and other infrastructure. Investing in human capital, defined as the health, knowledge, skills, experience and habits of people, usually interests them much less. This is wrong, since neglect of investment in human capital can drastically weaken a country's competitiveness in a rapidly changing world $-\mathrm{a}$ world in which more and more highly qualified specialists are required to ensure sustainable economic growth.

Scientists are well aware of the diverse benefits of improving the quality of human capital. However, their knowledge did not translate into a compelling call to action for developing countries. One of the obstacles is the lack of convincing data that would clearly demonstrate the profitability of investing in human capital not only to ministers of health and education, but also to heads of state, ministers of finance and other influential officials in different countries of the world. That is why the human capital index, calculated for different countries, can stimulate growth in the volume and efficiency of investment in people.

Over the past thirty years, the difference in life expectancy in rich and poor countries has begun to decline gradually. The coverage of school education has expanded many times. It should be noted that the degree of development of human capital varies greatly between countries and regions, while some people have the opportunity to receive free, high-quality education, a medical examination, others cannot satisfy their basic needs for food and housing. In the recent decade, the management of organizations has found that human resources have the greatest importance in gaining sustainable competitive advantage and efficiency (Pasban, 2016: 249-253).

Next, we consider the problems of human capital development in developing countries using the example of South Asian countries.

Material and Methods. The South Asian region is unique in the world. According to the World Bank classification, it includes eight countries: Afghanistan, Bangladesh, Bhutan, India, Maldives, Nepal, Pakistan and Sri Lanka. These countries have historical, political, social and cultural ties that unite them with each other. They also have the largest workforce available to its industries and the largest pool of educational and research institutions. Political uncertainty, poor governance, corruption, human rights violations, poverty and a poor investment climate are important factors that cannot be ignored when discussing national policies and practices in the field of human capital development in the context of South Asian countries.

In order to compare the degree of development of human capital by country, it became necessary to create a quantitative assessment of human resources. One of such indicators is the Human Capital Index, which was developed by the World Bank and is used to characterize the state of human capital by country, draw conclusions on the results of work and create new projects to improve the quality of human capital. The first version of the human capital index was published at the IMF and WBG annual meetings in Bali, Indonesia, in October 2018. This simple crosscountry metric is expected to attract the political attention needed for actions aimed at investing in human capital around the world.

For a comparative analysis, the Human Capital Indices of countries occupying the five first and last places are presented according to the rating presented by the World Bank. The results of South Asian countries are also shown in Table 1. According to the World Bank, it can be concluded that South Asians are not able to realize $50 \%$ of their potential, Sri Lan$\mathrm{ka}$ is the most developed country in terms of human capital, where the indicator exceeded half (World Bank, 2018) - Table 1:

Table 1 - Human Capital Index of developing countries in South Asia in comparison with the first and last five countries of the world for 2018*

\begin{tabular}{|c|c|c|}
\hline № & Country & Human Capital Index, HCI \\
\hline 1 & Singapore & 0.88 \\
\hline 2 & Korea, Rep & 0.84 \\
\hline 3 & Japan & 0.84 \\
\hline 4 & Hong Kong SAR, China & 0.82 \\
\hline 5 & Finland & 0.81 \\
\hline
\end{tabular}




\begin{tabular}{|c|c|c|}
\hline № & Country & Human Capital Index, HCI \\
\hline \multicolumn{2}{|c|}{$\ldots$} \\
\hline 1 & Sri Lanka & 0.58 \\
\hline 2 & Nepal & 0.49 \\
\hline 3 & Bangladesh & 0.48 \\
\hline 4 & India & 0.44 \\
\hline 5 & Afghanistan & 0.39 \\
\hline 6 & Pakistan & 0.39 \\
\hline \multicolumn{2}{|c|}{$\ldots$} & 0.32 \\
\hline 1 & Liberia & 0.32 \\
\hline 2 & Mali & 0.32 \\
\hline 3 & Niger & 0.30 \\
\hline 5 & South Sudan & 0.29 \\
\hline
\end{tabular}

*Note: Compiled by the authors based on data provided in source (World Bank, 2018).

There are many problems that impede the development of human capital in the countries of South Asia and they appear in each country differently.

There is a specific problem which occurs especially three countries of South Asia.

Fertility growth at an accelerated pace affects the quality of human capital. This reduces per capita availability of existing facilities such as sanitation, jobs, sewage, water supply, housing, hospitals, education, food supply, etc. India is the largest country in South Asia. As of January 2020, 1,388 million people live in India, which is $17.87 \%$ of the total population of the earth. Other countries in South Asia with a large population: Pakistan - almost 208 million (2.67\%) and Bangladesh - almost 170 million (2.19\%).

Results and Discussion. The remaining problems below are manifested in all countries of South Asia, especially in India, Bangladesh, Sri Lanka and Afghanistan.

1. Nutrition and food shortages. Due to a large population growth of $1.2 \%$ in 2019 , India faces such a problem as food shortages. This represents $22 \%$ of the disease burden in India and negatively affects economic growth with an estimated adult productivity loss of $1.4 \%$ of GDP. There is no access to drinking water, due to which about 200 thousand people die every year (World Bank, 2018).

Bangladesh faces one of the most serious malnutrition problems. According to data from 2017, 24 million people are starving. 61 million children suffer from malnutrition and other developmental problems. Currently, per capita consumption is only 1850 kilocalories, which is by any standard much lower than the required requirement (World Bank, 2018).
Malnutrition arises from the convergence of poverty, the unfair distribution of food, disease, illiteracy, rapid population growth and environmental risks, exacerbated by cultural and social inequalities.

Afghanistan has one of the highest levels of child malnutrition in the world. About $36.6 \%$ of children under the age of five suffer from chronic malnutrition, and women and children suffer from a high level of deficiency of vitamins and minerals (World Bank (Afghanistan), 2019: 56). More than half of Afghan girls and boys suffer from damage to their minds and bodies, which cannot be fixed because they eat poorly in the first two years of life.

2. Lack of health care. In India, government spending on public health is a meager $1.6 \%$ of GDP compared to a global average of $6 \%$. Despite impressive fertility rates of 27.6 million people in 2018 , infant and child mortality rates are high -38 and 48 deaths per 1000 children, respectively, 30 to 100 among the adult population while the average life expectancy among the population is 68.8 (135th place in the ranking of UN countries by life expectancy). High mortality is associated with a shortage of specialists. The ratio of doctors to residents is 1: 1700, which is less than the WHO prescribed 1: 1000. The unwillingness of doctors to serve rural areas stems from a sense of professional isolation and inequality in living conditions. There are almost four times more practicing doctors in the city than in rural areas per 10,000 people.

According to 2018 data, life expectancy at birth in Bangladesh is approximately 70 years, slightly higher than the World Health Organization average of 69 years. Despite improved maternal health, Ban- 
gladesh still ranks fourth in the world in terms of infant mortality under one year, with approximately 27 deaths per 1000 live births in 2017. Only one in four births occurs in a medical facility, putting both mothers and children at risk. Although infant and child mortality is declining, poor nutrition is a serious public health problem in Bangladesh. Maternal mortality accounts for 176 to 100,000 live births (World Bank, 2018). About half of the children aged 6-59 months suffer from anemia; four out of ten are stunted; and one in three is underweight. Bangladesh has one of the most severe childhood malnutrition problems in the world. Infectious diseases are the leading cause of death and disability in Bangladesh. The country is still among the top ten countries in the world with the highest burden of tuberculosis.

According to the WBG, only $83 \%$ of children under the age of five in the country are not stunted. This situation is observed in Sri Lanka. Sri Lanka's Human Development Report showed that 30 percent of the poor in the country account for poor nutrition. Although the country has initiated several programs in this area, the nutritional status of children under the age of five has improved only slightly. For example, studies show that from 2006 to 2016, the percentage of underweight children in the country decreased by less than one percentage point, from $21.1 \%$ to $20.5 \%$ (World Bank, 2018).

Afghanistan's state budget for basic health services is sufficient to maintain current levels of care. Almost $7 \%$ of the population lives at least two hours from the nearest medical facility by any means of transport (Government of Islamic Republic of Afghanistan, 2018: 23). Poor people are generally excluded from public services because they often cannot bear the costs of accessing them (for example, the cost of transport to get to the nearest school or medical facility). The World Bank estimates that for every 50,000 people in Afghanistan there is only 1 doctor, while in the United States this figure is about 1 doctor for every 350 people. Institutions are in urgent need of rehabilitation and there are inadequate supplies of medicines, vaccines, equipment and fuel (World Bank, 2018).

3. The scope of education. According to the IBEF report, the total enrollment rate in higher education in 2016-17 in India was 25.2\%, which is lower than in the United States $(85.8 \%)$ and China (43.39\%). The literacy rate in India is only $72 \%$, which is lower than the world literacy rate of $86 \%$, according to a UNESCO report (UNESCO, 2015: 132). The low quality of knowledge suggests that although the average Indian child will receive 10.2 years of formal education, and his quality is equivalent to only 5.8 years of standard education. Some children studying in the fifth grade do not know how to read and write. Nearly threequarters of third-grade students in rural India cannot solve the double-digit subtraction example.

Bangladesh spends less than 3\% of its GDP on the education sector, which is significantly lower than other countries, given that the average age of the population in 2018 was 25.6 years. The average adult literacy rate is $61.38 \%$ in 2018 , among youth this indicator is higher and equal to $83.13 \%$. In recent years, there has been a tendency to increase literacy among the female population, an increase in the number of students of girls. The UNESCO Institute for Statistics shows that literacy in Bangladesh still needs to be improved. Approximately $30 \%$ of the population aged 15 and over is still trying to successfully read and write. There is also no single curriculum in Bangladesh schools. Studies show that $35 \%$ to $40 \%$ of students in the country are not able to go to colleges or public universities. Of the 20 million children of primary school age, four million do not attend school and another four million or more drop out before completing primary education (UNESCO, 2015: 132). UNICEF believes that the problem of dropping out of Bangladesh arises from the need for children to help parents with farming, poor teaching methods, crowded classrooms, and an unattractive educational environment. The lack of qualified teachers and poor school equipment in terms of the number of schools, classrooms, libraries and playgrounds are responsible for the poor quality of education in primary schools.

According to a report published by the Ministry of Education of Afghanistan and UNICEF, almost half of Afghan children do not attend school due to factors such as nationwide conflict, poverty and forced marriage of children. This represents about 3.7 million or about $40 \%$ of children aged 7 to 17 years who are not receiving education. Girls make up $60 \%$ of children skipping classes, while in the most impoverished areas this percentage reaches $85 \%$. The country also needs more female teachers to encourage girls to attend school (Jabarkhail S., Dooley L.M., 2019). In the 21 st century, getting a higher education is a dream for women in Afghanistan, a dream that may not come true. The higher education system in Afghanistan also has problems. The percentage of people attending universities in Afghanistan is only $8 \%$, compared with India (18\%) and Malaysia (42\%), which means that access to higher education is limited. There is also poor quality of abilities, low student rewards, inadequate teaching methods, outdated curricula, poor leadership and student control for those at the university, combined with a huge lack of support and analysis. This has led to the fact that a huge 
number of students do not receive and do not acquire the necessary skills necessary for them to make a significant contribution to the working and social environment in Afghanistan or on a global scale. Most teachers in private schools lack qualifications, so they are considered illiterate and inexperienced.

One area where Sri Lanka is performing poorly is quality-adjusted years of study. The expected number of years of schooling for a child born in Sri Lanka today is 13 years, but as a result, after adjusting for quality education, the school index in Sri Lanka drops to 8.3 years, which indicates that almost five years out of 13 do not lead to additional training. According to the Ministry of Education, about half of students do not pass the exam at the general educational level, mainly because of mathematics. Sri Lanka lacks qualified and experienced teachers, mainly due to problems with training, recruitment and placement. Only $35 \%$ of the population aged 15 and over have completed secondary education in Sri Lanka and only $13.3 \%$ have a university degree (Ranasinghe, J., 2018: 34-38).

Nonetheless, the Sri Lanka HDI is the best in the South Asian region (0.58). However, a figure of 0.58 indicates that Sri Lanka is 42 percent lower than its potential.

The World Bank is facing such challenges in building human capital. A wide range of problems requires a large-scale, diversified approach to solving them. Consider what projects the World Bank has undertaken in selected countries.

Human capital is a priority in South Asia. Sri Lanka, the highest ranked country in South Asia, ranks 74 (out of 157 countries) on the HCI. But overall, South Asia ranks low with high child stunting rates and low-quality education in most South Asian countries. Significant investments are now underway to improve the quality of health and education throughout the region. Bhutan and Pakistan are early adopters of the Human Capital Project.

South Asia is the second-largest region for the International Development Association (IDA), with an IDA18 core allocation of above $\$ 10$ billion - $\$ 6.1$ billion in fiscal year 2018 and $\$ 4.9$ billion in fiscal year 2019. IDA has spurred transformative changes in South Asia. India and Sri Lanka graduated from IDA in 2017. Its goal is to help other South Asian countries reach that goal.

In India, between 2000-01 and 2017-18, IDA helped an extra 33 million students enroll in elementary school (from 156.6 million students in 200001 to 189.9 million in 2017-18). Since 1997, World Bank-supported programs have provided treatment to more than 20 million tuberculosis patients, avert- ing 3.5 million deaths. Since 2000, IDA has helped 36 million people in 40,000 villages gain access to better drinking water.

In Sri Lanka, with IDA support, all public universities and some private higher education institutions now offer courses to equip undergraduate students with the skills they need on the global market (Ranasinghe, J., 2018: 34-38). Existing school libraries have received more than 1,500,000 library books in 3,062 titles in Sinhala, Tamil and English. New libraries got 100,000 book sets. IDA helped redevelop the conflict-affected North and East of Sri Lanka, including the completion of $790 \mathrm{~km}$ of rural roads, 49 $\mathrm{km}$ of flood storm drainages, four rural water supply schemes, 400 public facilities (such as markets, parks, playgrounds, and cemeteries), and $11 \mathrm{~km}$ of rural electrification schemes.

In Bangladesh, the Private Sector Development Support Project has helped attract nearly $\$ 3$ billion of investment, generated more than 23,000 jobs, and altered the industrial zone landscape of Bangladesh. In Pakistan, \$198 million was generated in private investment across manufacturing, health and beverage sectors through the Punjab Jobs and Competitiveness Program (World Bank, 2019).

There are also many government programs aimed at developing human capital in each country of South Asia.

In April 2019, Prime Minister Khan of Pakistanlaunched a flagship program focused on investing in people, reducing inequality, and lifting lagging districts. It uses modern data and technology to focus on the central role of human capital formation for poverty eradication, economic growth, and sustainable development.

At the Pakistan Human Capital Summitin Islamabad in March 2019 held in conjunction with the launch of the Pakistan@100 Report, human capital messages were broadcast nationwide by the media and country leaders. Pakistan@100: Shaping the Future (March 2019) argues that Pakistan's young and growing population of 208 million is its greatest asset. Capitalizing on a demographic dividend will be essential to double the country's productivity.

A joint Bhutan-NepalForum was held in Kathmandu in June 2019 to elevate the human capital agenda with political leaders and government officials across different ministries, media and civil society. The Forum sought to craft a vision for human capital development of the two countries. As a result, Nepal announced $22 \%$ increase for social sectors next year.

Human Capital National Priority Program (2018) of Government of Afghanistan considers univer- 
sal and quality health care services, outcome-based and standardized education programs, market-driven higher education and training programs and efficient, effective social protection programs.

Even if such programs are implemented, there are problems that reduce the effective use of human capital in developing countries.

1. Corruption in the education sector. In Afghanistan, findings on ghost teachers, students and schools as well as the buying and selling of teacher positions have significantly eroded trust in the education sector. Recent reports and surveys on the vulnerability to corruption and girls' education indicate critical governance challenges that range from teacher management to corrupt practices in the recruitment of teachers. Similarly, lack of a rigorous and transparent system for allocation and delivery of resources such as teacher recruitment, delivery of textbooks, and school construction continue to negatively impact the intended outcomes of investments in the sector.

In India, $61 \%$ of educational institutions are subject to corruption. India's education system is mired in corruption and a high rate of teacher absenteeism in the country was a key factor for it according to the new global study.

2. Brain drain. Brian drain refers the situation when highly qualified and trained people leave a country to permanently settle in some other country. It is also referred to as 'human capital flight'. Highly educated professional people immigrate to other advanced countries for better opportunities and a comfortable life style.

As economist Aneesh K.A. mentioned, "after independence India is engaged in difficult struggle against poverty. But struggles cannot be launched in papers; they require armies of trained technical knowhow and specialists in the field of planned development" (Aneesh K., 2019: 1-26). If, instead of contributing to the prosperity of India, the Indian scientists, research scholars, engineers, doctors and economists immigrate to other countries, it is difficult to see how India can implement her development plans and attain her goal of prosperity. In last decade, brain drain from India is happening at an alarming rate, and the statistics will open your eyes more clearly.

Educated unemployment is one of the most popular forms of unemployment visible in India itself reflects the failure of the government to better utilize the demographic dividend opens exclusively for India (Aneesh K.A., 2016: 359-375). India's high educated unemployment rate is the most important reason for this alarming human capital flight from India. Jobs are not matching the growth in population, and lakhs of graduates remain unemployed every year, and they have no option to fly to foreign in search of job. Though the government has been implementing industrial liberalization policies since 1991, most of the fiscal and industrial policies are still a pulling factor of the entrepreneurs back from starting a new venture in India. The rampant corruption and no value of talent is the another factor for brain drain in India. Better life style and currency difference also make thinking the talented youngsters roost to foreign countries. In 2018, more than 554 thousand citizens migrated from the country.

3. Unemployment. Even if there are many educational programs, in some countries the quality of education is very low, which cannot provide the labor market with competent specialists. In other countries, governments cannot provide jobs for trained professionals.

For example, the national unemployment rate stands in Afghanistan at nearly 24\%, with two million people classified as unemployed, and youth unemployment is nearly $31 \%$. Of those who are employed, only $20 \%$ are in secure positions, with the remaining $80 \%$ of the workforce having less secure employment. With Afghanistan's burgeoning youth demographic, the labour market is expected to have 1.6 million new entrants in the next five years and lead to the danger of unemployment levels rising further (Government of Islamic Republic of Afghanistan, 2018). The current status of unemployment and underemployment in the country is partially due to the fact that current education policies in Afghanistan are not structured to meet market demand and are unlikely to fit future labour market needs. The competencies of many graduates are not at the level required for entering the workforce and a large share of courses offered are not linked to market demand.

A spectrum of labor and human capital institutions have existed historically (Goldin C., 2014: 5). As we can see, many workers in developing countries still face social problems such as unemployment, low pay and poor working conditions.

Issues related to the labor market constantly torment both the authorities of developing countries and the population. This is not surprising: all sorts of problems in this area are given with acute pain in all directions of the social organism. Here is an incomplete list of the most urgent of them: 1) unemployment, especially youth and especially in singleindustry towns; 2) extremely low labor productivity; 3) low wages and high levels of inequality; 4) high proportion and continued growth of the informal sector; 5) educational imbalances (university graduates very often do not work in their specialty or occupy less qualified jobs). 
The common denominator is this: the economies of developing countries do not generate enough decent-quality jobs or creates very few of them. To solve the problem, it is only necessary that the economy creates new jobs all the time and everywhere. Then old jobs will be eliminated. Education and qualifications will be used more fully. Informal employment will decrease. Unemployment will decrease, and people will become more mobile. In general, most of the socio-economic problems that are directly or indirectly related to the labor market are beginning to resolve, and there is no other way in nature.

Job creation is a system golden key, which, however, is not so easy to use. The belief that the state will be able to solve this problem manually and with budget money is not even an illusion, but criminal naivety. Therefore, help must come from outside.

The World Bank should consider the link between educational programs and employment, as well as the possible contribution of official development assistance and external borrowing to maintain employment in developing countries. This means that World Bank assistance must be comprehensive so that it can address the side effects of single industry assistance.

How are jobs created? There are only two sources: the creation of new enterprises and the expansion of existing ones. In the countries of Central and Eastern Europe, the first one is the main one: it accounts for $40 \%$ to $70 \%$ of newly created jobs. Developing countries have a bad situation with both. Enterprises are rarely born and in heavy torment. Grow slowly and reluctantly. The way from an idea to the beginning of its implementation takes years. At the same time, research suggests that the newly created enterprises make the largest contribution to the creation of new jobs. It is at the initial stage of their life cycle that they most quickly generate employment. Old enterprises are often reduced than expanded.

New jobs, as a rule, are more productive, use more modern technologies, require a better education. Replacing old jobs with new ones is one of the most important sources of labor productivity growth.

In developing countries, job creation also means poverty reduction, the normal functioning of cities, and also the creation of prospects for young people that provide them with opportunities for creation, not violence.

"Good work can change a person's life, and much-needed jobs can transform society as a whole. Job creation should be a priority for governments to promote prosperity and fight poverty in their countries, "said World Bank Group President Jim Yong Kim. "It is very important that governments work effectively with the private sector, which accounts for $90 \%$ of all jobs. Therefore, we need to find the most effective way to stimulate the growth of small enterprises and farms. Jobs give people hope and are the key to peace. Thanks job creation, the situation in countries on the brink of conflict can stabilize".

Creation of highly productive jobs has the greatest effect on the growth of population incomes, improves the functioning of cities, strengthens the economic ties of countries with world markets, helps protect the environment and increase the role of the population in making socially important decisions.

However, in many developing countries, where the majority of workers are employed in agriculture and self-employment prevails, where the social security system is poorly developed or practically absent, the unemployment rate may be low. In such countries, the majority of the poor have a long working day, but can barely feed themselves. Moreover, violations of fundamental rights are by no means a rare occurrence. That is why providing not only quantity, but also quality of jobs is a vital task.

A three-step approach to solving the employment problem is proposed, which will help governments achieve their goals:firstly, it is necessary to ensure stable fundamental indicators, including macroeconomic stability, a favorable business environment, human resources and the rule of law;secondly, labor relations policies should not be an obstacle to job creation, and should also ensure the protection of interests and access to social assistance for the most vulnerable segments of the population;thirdly, developing countries should determine which jobs are most conducive to development, taking into account the specific circumstances of the country, and remove or neutralize the obstacles to job creation in the private sector.

Conclusion. The modern economy is the economy of effective human capital, which emphasizes its main role in the development of the economy and society as a productive factor. Human capital is becoming the most important factor in the country's economic growth, the foundation of sustainable economic development. International experience confirms that investments in human capital and, in particular, in education, from early childhood to adulthood, contribute to significant returns for the economy and society, and the country's economic growth.

Despite unprecedented successes in human development over the past 25 years, serious challenges remain, especially in developing countries.

Human capital development is at the center of the World Bank's global development strategy. Investing in people is one of the three areas of activity of organizations to achieve the dual goal of eradicating 
extreme poverty by 2030 and ensuring common prosperity in all countries.

The "Human Capital Development Project" is a global program of action to accelerate investment in people for the achievement of social justice and economic growth. The World Bank is proud of its contribution to numerous successes in human capital development and initial investment but human resource productivity depends on the availability of tangible assets, such as infrastructure, equipment, and a stable, efficiently managed economy. For this reason, the World Bank should consider the link between educational programs and employment, as well as the possible contribution of official development assistance and external borrowing to maintain employment in developing countries. This means that World Bank assistance must be comprehensive so that it can address the side effects of single industry assistance.

\title{
References
}

Aneesh K (2019), Human Capital and Endogenous Growth in India: Where Does India fail to Capitalise Its Human Power? // Social Science Researcher,. №5-1. P. 1-26.

Aneesh K.A. (2016),Harnessing Demographic Dividend: India's Hurdles to Jump // Social Action. Indian Social Institude., Vol. 66. P. 359-375.

Fisher I. (1996) The nature of capital and income // New York: Macmillan, 1996. P. 168.

Fetter,Frank A. (2019),Modern Economic Problems // Economics, 2019. Vol. 11. P. 619.

Goldin C., Human Capital (2014) // Harvard University and National Bureau of Economic Research, 2014. P. 40.

Pelinescu E. (2015), The Impact of Human Capital on Economic Growth // Economics and Finance, 2015. Vol. 22. P. $184-190$.

Pasban M. A (2016), Review of the Role of Human Capital in the Organization // Social and Behavioral Sciences, №230. P. 249 -253 .

Pande A. (2017),South Asia's Human Capital Crisis // Hudson Institude. Huffington Post,

Ranasinghe, J. Human Capital and Economic Growth in Sri Lanka (2018) // Proceedings of The International Conference on Economics and Development, 2018. №2(1). P. 34-38.

Jabarkhail S., Dooley L.M. (2019),Human Resource Development: Why It Matters in the National Context of Afghanistan // South Asian Journal of Human Resources Management, 2019.

World Bank. (2018), Human Development Statistical Update,

World Bank. (2019), The World Bank in Afghanistan, P. 56.

World Bank. (2019),Human Capital Project First Year Annual Progress Report, P. 17.

UNESCO. (2015),Adult and Youth Literacy // National, regional and global trends, P. 132.

T. Muravska ${ }^{1}$, Л.А. Медуханова ${ }^{2}$, А.Ж. Бекмурза²

${ }^{1}$ Рижский Государственный университет бизнес-администрирования, Латвия, г. Рига

${ }^{2}$ Казахский национальный университет им. аль-Фараби, Казахстан, г. Алматы

\section{Проблемы развития и эффективного использования человеческого капитала в развивающихся странах}

\begin{abstract}
Аннотация. В статье рассматриваются основные проблемы развития человеческого капитала в прогрессирующих странах. Основной целью статьи является выявление проблем эффективного использования человеческого капитала в развивающихся странах. Актуальность статьи заключается в обосновании экономического содержания человеческого капитала, анализе основных показателей и показателей развития человеческого капитала в развивающихся странах по сравнению с другими странами мира, проведении сравнительного анализа проблем эффективного использования человеческого капитала по странам и роли Всемирного банка в развитии человеческого капитала. В статье определены проблемные вопросы проектов по развитию человеческого капитала. Общей методологической основой статьи являются общенаучные методы познания, используемые для теоретического анализа экономических явлений. Результаты исследования подтверждают необходимость внесения дополнений в программы развития человеческого капитала и выдвигают идеи создания условий и факторов для его эффективного развития с целью создания инновационной экономики будущего. Предложены пути совершенствования программ развития человеческого капитала.

Ключевые слова: человеческий капитал, развивающиеся страны, индекс человеческого капитала, эффективное использование человеческого капитала, комплексное содействие.
\end{abstract}


Т. Muravska ${ }^{1}$, Л.А. Медуханова ${ }^{2}$, А.Ж. Бекмұрза²

${ }^{1}$ Рига мемлекеттік іскерлік әкімшілік университеті, Латвия, Рига к.

²Ә-Фараби атындағы Қазақ ұлттық университеті, Қазақстан, Алматы қ., e-mail: medukhanova.1@gmail.com

\section{Дамушы елдердегі адами капиталды дамыту және тиімді пайдалану мәселесі}

Аңдатпа. Мақалада дамушы елдердегі адами капиталды дамытудың негізгі мәселелері талқыланады. Мақаланың негізгі мақсаты - дамушы елдердегі адами капиталды тиімді пайдалану мәселелерін анықтау. Мақаланың өзектілігі - адами капиталдың экономикалық мазмұнын негіздеу, әлемнің басқа елдерімен салыстырғандағы дамушы елдердегі адами капиталды дамытудың негізгі көрсеткіштерін талдау, елдердің адами капиталды тиімді пайдалану мәселелеріне және Дүниежүзілік банктің адам капиталын дамытудағы рөліне салыстырмалы талдау жүргізу. Мақалада адами капиталды дамыту жобаларының проблемалық мәселелері көрсетілген. Мақаланың жалпы әдіснамалық негізі - экономикалық құбылыстарды теориялық талдау үшін қолданылатын танымның жалпы ғылыми әдістері. Зерттеу нәтижелері адами капиталды дамыту бағдарламаларына толықтырулар енгізу қажеттілігін және болашақтың инновациялық экономикасын құру үшін, оның тиімді дамуы үшін жағдайлар мен факторларды қалыптастыру қажеттілігін растайды. Адами капиталды дамыту бағдарламаларын жетілдіру жолдары да қатар ұсынылған.

Түйін сөздер: адами капитал, дамушы елдер, адами капитал индексі, адами капиталды тиімді пайдалану, кешенді көмек. 